\title{
THE RELATION OF THYROID AUTO-IMMUNITY TO ROUND-CELLED INFILTRATION OF THE THYROID GLAND
}

\author{
BY \\ R. O. K. SCHADE, S. G. OWEN, G. A. SMART, AND R. HALL \\ From King's College, University of Durham, and the Royal Victoria Infirmary, Newcastle upon Tyne
}

(RECEIVED FOR PUBLICATION JULY 13, 1960)

The relationship between thyroid auto-immunity and the presence of lymphocytes in the thyroid gland has been analysed in patients with Graves' disease, toxic adenoma, and non-toxic nodular goitre. In all these conditions circulating antibody to thyroglobulin was significantly associated with lymphocytic infiltration. No similar correlation was established in the case of the complement-fixing antibody.

Complement-fixing antibody was significantly commoner in Graves' disease (diffuse thyrotoxic goitre) than in toxic adenoma and non-toxic nodular goitre. Circulating thyroglobulin antibody probably originates from lymphoid tissue within and around the thyroid gland itself.

Overactivity of pituitary thyrotropin may favour immunization to the intracellular (complementfixing) antigen.

Circulating auto-antibodies to thyroid constituents, which are usually present in Hashimoto's thyroiditis and non-goitrous myxoedema, can also be demonstrated in a proportion of cases of Graves' disease and non-toxic adenomatous goitre (see recent reviews by Roitt and Doniach, 1960 ; and Smart and Owen, 1960). So far as we are aware, no systematic study has been made of the relationship in the latter conditions between serological reaction and the histological appearance of the thyroid gland. Roitt and Doniach (1958) stated that localized lymphoid infiltration was found at operation in the majority of their patients with thyrotoxicosis who gave positive antibody tests and in some who did not. In nine patients without clinical thyroid disorder whose sera had given "false positive" complementfixation reactions with thyroid extract, Goudie, Anderson, and Gray (1959) were able to examine the gland at necropsy and noted the presence in eight of these of lymphocytic foci and Askanazycell change ; similar appearances were also found in nine subjects who had given negative complement-fixation reactions. On the basis of this partial correlation, it was suggested that the histological abnormality might be due to the action of auto-antibody on thyroid tissue. The value of the study, however, was lessened by being limited to the less specific of the two identified autoimmune systems, that directed against an intracellular, microsomal constituent ; the other, which involves thyroglobulin, is not only organ specific, but is much more constantly demonstrable in human "auto-immune thyroiditis."

The matter seemed to us to warrant further attention. A statistically valid comparison between histology and serology in conditions only sometimes associated with auto-immunity was needed to determine to what extent antibody tests can predict pathological changes, and whether they should be accorded clinical significance. It might also throw light on a more fundamental problem: Is auto-immunity an unimportant epiphenomenon of thyroid damage or overstimulation, due to leakage of antigenic components and antibody production by the peripheral reticulo-endothelial system ? Or does the antibody in the blood stream originate from the gland itself and therefore signify a self-destructive invasion by the immune defences?

The results of such a study, based on a retrospective analysis of surgical specimens of thyroid tissue recently submitted for routine histological examination to the Department of Pathology, are reported here. 


\section{Material and Methods}

The histological material which formed the starting point of the investigation consisted of excised portions of thyroid gland from 54 patients recently operated upon for either diffuse thyrotoxic or adenomatous goitre (19 and 35 cases respectively). Seventy-nine cases were originally selected from the total material available by one of us (R.O.K.S.), the bases of selection being adequacy of sections from each specimen in respect of number and quality and the inclusion of approximately equal numbers in which infiltration with lymphocytes and plasma cells and lymphadenoid collections were $(a)$ obvious and of at least moderate degree, and (b) absent or negligible. Other histological abnormalities such as Askanazy-cell change in the thyroid epithelium and the presence of multinucleated giant cells were not taken specifically into account, though these were also often present in group (a). Fifty-seven of the patients concerned were successfully contacted and proved willing to provide a specimen of blood for immunological study. The sections were then reviewed independently by G.A.S., whose assessment of the extent of lymphoid invasion was found to coincide with the original classification in all except two instances; the cases in dispute were on that account discarded from the analysis. R.H., without knowledge of either the histological or serological findings, subsequently examined the pre-operative clinical and laboratory data in order to confirm that the stated clinical diagnosis had been adequately established; a third case was rejected on the grounds of doubt about the true state of thyroid function before thyroidectomy, leaving a final total of 54 . There was evidence of increased thyroid function pre-operatively in all 19 patients with Graves' disease and in nine of those with nodular goitre, the remainder being euthyroid. The three clinical groups each comprised approximately equal proportions with and without lymphocytic infiltration of the gland (Table I).

TABLE I

CLASSIFICATION OF 54 CASES ON BASIS OF PRE-OPERATIVE DIAGNOSIS AND HISTOLOGICAL INFILTRATION WITH LYMPHOCYTES

\begin{tabular}{|c|c|c|c|}
\hline Diagnosis & $\begin{array}{l}\text { No. of } \\
\text { Cases } \\
\text { (Total) }\end{array}$ & $\begin{array}{l}\text { No. with } \\
\text { Appreciable } \\
\text { Lymphocytic } \\
\text { Invasion }\end{array}$ & $\begin{array}{l}\text { No. with } \\
\text { Negligible } \\
\text { Lymphocytic } \\
\text { Invasion }\end{array}$ \\
\hline 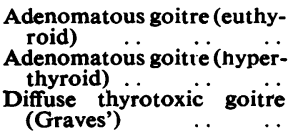 & $\begin{array}{r}26 \\
9 \\
19\end{array}$ & $\begin{array}{r}14 \\
5 \\
10\end{array}$ & $\begin{array}{r}12 \\
4 \\
9\end{array}$ \\
\hline Totals $\ldots$ & 54 & 29 & 25 \\
\hline
\end{tabular}

Antibody to thyroglobulin was estimated by an adaptation of the tanned red cell agglutination technique (Boyden, 1951), the details of which have been described elsewhere (Owen and Smart, 1958); the cells were coated with antigen by treatment with a suitably diluted and buffered high-speed supernate of a homogenate of human thyroid gland. Standard complement-fixation technique was used for estimating the complement-fixing antibody, following in essentials that employed by Roitt and Doniach (1958); antigen was prepared from thyrotoxic tissue and was subjected to low-speed centrifugation only. All serological tests were carried out by one of us (S.G.O.) without knowledge of the histological classification.

Histological and serological data were then compared, with the results summarized below. Though antibody levels were estimated quantitatively, only the presence or absence of each antibody has been considered for purposes of analysis. This was dictated by the retrospective nature of the study, serology having been carried out at varying intervals after partial thyroidectomy. The high titres characteristic of active Hashimoto's disease are known to drop sharply within a year of thyroidectomy (Owen and Smart, 1958), so it is likely that observed levels among the present patients variably underestimate those existing at the time of operation. (By chance. the sera of five patients had been submitted to the laboratory before thyroidectomy, and of these two were positive ; though still positive on re-testing during the study, the antithyroglobulin concentration had fallen from 7 to 4 logarithmic units in one and from 10 to 2 units in the other over respective periods of three and 12 months.) It is possible that depression below the threshold necessary for detection in some cases may have led to the overall frequencies reported here being falsely low, but any such effect will be small since in our experience antibody, to thyroglobulin at least, rarely disappears entirely.

\section{Results}

Considering the two immune systems together, there was a highly significant positive association between auto-immunity and round-celled infiltration (Table II). When type of antibody is taken into account, the correlation is seen to depend almost entirely on that to thyroglobulin; though positive complement-fixation reactions were somewhat commoner in the lymphadenoid group, the difference is not statistically significant (Table III).

TABLE II

RELATION BETWEEN LYMPHOCYTIC INFILTRATION AND THYROID AUTO-IMMUNITY

\begin{tabular}{|c|c|c|c|}
\hline \multicolumn{2}{|c|}{$\begin{array}{l}\text { Histological Assessment of } \\
\text { Lymphocytic Infiltration }\end{array}$} & $\begin{array}{l}\text { No. of } \\
\text { Cases }\end{array}$ & $\begin{array}{l}\text { No.Showing Auto-immunity } \\
\text { (to Either or Both Antigens) }\end{array}$ \\
\hline $\begin{array}{l}\text { (a) Appreciable } \\
\text { (b) Negligible }\end{array}$ & & $\begin{array}{l}29 \\
25\end{array}$ & $20(69 \%)\} \chi^{2} \mathrm{c}=15.2 \mathrm{P}<0.001$ \\
\hline
\end{tabular}

TABLE III

RELATION BETWEEN LYMPHOCYTIC INFILTRATION AND INDIVIDUAL ANTIBODIES

\begin{tabular}{|c|c|c|c|}
\hline $\begin{array}{c}\text { Histological } \\
\text { Assessment } \\
\text { of } \\
\text { Lymphocytic } \\
\text { Infiltration }\end{array}$ & $\begin{array}{c}\text { No. } \\
\text { of } \\
\text { Cases }\end{array}$ & $\begin{array}{l}\text { No. with } \\
\text { Antibody to } \\
\text { Thyroglobulin }\end{array}$ & $\begin{array}{c}\text { No. with } \\
\text { Antibody to } \\
\text { Complement-fixing } \\
\text { (Microsomal) } \\
\text { Antigen }\end{array}$ \\
\hline $\begin{array}{l}\text { (a) Appre- } \\
\text { ciable } \\
\text { (b) Negligible }\end{array}$ & $\begin{array}{l}29 \\
25\end{array}$ & $\left.\begin{array}{rr}17(59 \%) \\
1 & (4 \%)\end{array}\right\} \begin{array}{l}\chi^{2}=15.6 \\
P\end{array}<0.001$ & $\left.\begin{array}{l}8(28 \%) \\
2(8 \%)\end{array}\right\} \begin{array}{l}\chi^{2} \mathrm{c}=2.2 \\
\mathrm{P}<0.20>0.10\end{array}$ \\
\hline
\end{tabular}


TABLE IV

RELATION BETWEEN DIAGNOSTIC CLASSIFICATION AND AUTO-ANTIBODIES

\begin{tabular}{|c|c|c|c|c|c|}
\hline \multirow{2}{*}{$\begin{array}{c}\begin{array}{c}\text { Classification } \\
\text { on Basis of } \\
\text { Diagnosis }\end{array} \\
\text { (a) Adenomatous } \\
\text { goitre } \\
\text { (euthyroid) } \\
\text { (b) Adenomatous } \\
\text { goitre } \\
\text { (hyperthy- } \\
\text { roid) } \\
\text { (c) Diffuse thyro- } \\
\text { toxic goitre } \\
\text { (Graves') }\end{array}$} & \multirow{2}{*}{$\begin{array}{c}\begin{array}{c}\text { No. } \\
\text { of } \\
\text { Cases }\end{array} \\
26 \\
9\end{array}$} & \multicolumn{2}{|c|}{$\begin{array}{l}\text { No. with } \\
\text { Antibody to } \\
\text { Thyroglobulin }\end{array}$} & \multicolumn{2}{|c|}{$\begin{array}{c}\text { No. with } \\
\text { Antibody or } \\
\text { Complement-fixing } \\
\text { (Microsomal) } \\
\text { Antigen }\end{array}$} \\
\hline & & $\left.\begin{array}{l}8(31 \%) \\
3(33 \%) \\
7(37 \%)\end{array}\right\}$ & $\chi^{2} \mathrm{c} \sim 0$ & $\left.\begin{array}{l}2(7 \cdot 7 \%) \\
1(11 \%) \\
7(37 \%)\end{array}\right\}$ & $\left\{\begin{array}{l}x^{2} \mathrm{c}=4.5 \\
\mathrm{P}<0.2>0.1\end{array}\right.$ \\
\hline $\begin{array}{c}\text { (a) }+(b) \text { All } \\
\text { adenoma- } \\
\text { tous goitres } \\
\text { (c) Diffuse thyro- } \\
\text { toxic goitre } \\
\text { (Graves') }\end{array}$ & 19 & $\left.\begin{array}{r}11(31 \%) \\
7(37 \%)\end{array}\right\}$ & $\chi^{2} \mathrm{c} \sim 0$ & $\left.\begin{array}{l}3(8 \cdot 6 \%) \\
7(37 \%)\end{array}\right\}$ & $\begin{array}{l}\chi^{2} c=4.8 \\
P<0.05\end{array}$ \\
\hline $\begin{array}{l}\text { (a) Adenomatous } \\
\text { goitre } \\
\text { (euthyroid) } \\
\text { (b) }+(c) \text { All } \\
\text { hyperthyroid } \\
\text { goitres }\end{array}$ & 26 & $\left.\begin{array}{r}8(31 \%) \\
10(36 \%)\end{array}\right\}$ & $\chi^{2} \mathrm{c} \sim 0$ & $\left.\begin{array}{l}2(7 \cdot 7 \%) \\
8(29 \%)\end{array}\right\}$ & $\begin{array}{l}\chi^{2} \mathrm{c}=2.6 \\
\mathrm{P}<0.2>0.1\end{array}$ \\
\hline
\end{tabular}

Table IV relates frequency of auto-immunity to clinical diagnosis. As expected from the equal proportions of the two histological patterns, the incidence of thyroglobulin antibody did not vary between the three clinical groups. The presence of the complement-fixing antibody, on the other hand, was significantly related to the diagnosis of Graves' disease.

\section{Discussion}

Our findings are fully consistent with the view that thyroglobulin antibody in the circulation is derived from reticulo-endothelial elements within the gland itself (Burnet, 1959). They cannot indeed be interpreted otherwise, unless it be postulated that lymphocytic invasion is secondary to damage by antibody manufactured elsewhere and borne to the gland in the blood stream, a hypothesis which is unlikely in view of experimental evidence that exogenous antibody to thyroglobulin is harmless to intact thyroid tissue in vivo (Roitt and Doniach, 1958) and in tissue culture (Pulvertaft, Doniach, Roitt, and Hudson, 1959). It is true that one of our cases giving a serological reaction to thyroglobulin failed to show obvious lymphadenoid change on histology, but it is possible that this was an artefact introduced by limitations inherent in the retrospective method, in particular our inability to examine representative sections from all areas of the gland.

If antibody in the circulation does in fact represent spill-over from the auto-immune reaction in thyroid tissue, its presence and concentration will vary with the local balance between antibody and antigen. Thus the dense, uniform cellularity and the paucity of colloid characteristic of active Hashimoto's disease bespeak antibody predominance and explain the high titres associated with the condition. While the present overall incidence of thyroglobulin antibody was determined by histological selection and does not therefore reflect the natural frequency in the clinical groups studied, the observed frequency amongst the patients showing lymphoid changes (about $60 \%$ ) might be expected since the changes were usually only moderate and total fixation of antibody by antigen may often have occurred within the gland. At the moment these considerations remain to some extent speculative ; we hope to obtain more definitive evidence by extending the method to include approximate quantitative assessment of cellularity and tissue volume.

Failure to establish a similar association in the case of the complement-fixation antibody does not deny that one may exist ; the site and manner of formation remain uncertain. But the complementfixing property ipso facto invites speculation as to whether this antibody may not belong to a different order of immune defence, adapted to function in the circulation rather than the tissues. The homologous antigen, which has an intracellular distribution resembling that of the microsomes (Holborow, Brown, Roitt, and Doniach, 1959), is abundant only in thyrotoxic goitres (Trotter, Belyavin, and Waddams, 1957; Belyavin and Trotter, 1959), which presumably accounts for the higher incidence of the antibody in Graves' disease. The observation that hyperthyroidism complicating thyroid adenoma does not confer a similar increase in incidence is of some interest, since it suggests that overactivity of pituitary thyrotropin rather than hyperthyroidism per se may be responsible for exposure of this auto-antigen.

We are grateful to those physicians and surgeons of the Royal Victoria Infirmary who allowed us to study patients under their care. Our thanks are also due to Mrs. R. T. Johnson for her skilled assistance with the haemagglutination method.

\section{REFERENCES}

Belyavin, G.. and Trotter, W. R. (1959). Lancet, 1, 648

Boyden, S. V. (1951). J. exp. Med., 93, 107.

Burnet, M. (1959). The Clonal Selection Theory of Acquired Immunity. Cambridge University Press, London.

Goudie, R. B., Anderson, J. R., and Gray, K. G. (1959). J. Path. Bact., $77,389$.

Holborow, E. J., Brcwn, P. C., Roitt, I. M., and Doniach, D. (1959). Brit. J. exp. Path., 40, 583.

Owen, S. G., and Smart, G. A. (1958). Lancet, 2, 1034

Pulvertaft, R. J. V., Doniach, D., Roitt, I. M., and Hudson, R. V. (1959). Ibid., 2, 214 .

Roitt, I. M., and Doniach, D. (1958). Ibid., 2, 1027.

(1960). Brit. med. Bull., 16, 152.

Smart, G. A., and Owen, S. G. (1960). Postgrad. med. J., 36, 442. Trotter, W. R., Belyavin, G., and Waddams, A. (1957).' Proc. roy. Soc. Med., 50, 961 . 